EXTENDED REPORT

\title{
Mapping of the immunodominant T cell epitopes of the protein topoisomerase I
}

\author{
S Veeraraghavan, E A Renzoni, H Jeal, M Jones, J Hammer, A U Wells, C M Black, K I Welsh, \\ R M du Bois
}

See end of article for

authors' affiliations

Ann Rheum Dis 2004;63:982-987. doi: 10.1136/ard.2003.008037

Correspondence to: Professor R M du Bois, Interstitial Lung Disease Unit, National Heart and Lung Institute, Royal Brompton Hospital, 1B Manresa road, London SW3 6LR, UK; r.dubois@ rbh.nthames.nhs.uk

Accepted 25 November 2003
Objectives: To identify the immunodominant T cell epitopes of the topoisomerase I protein in patients with systemic sclerosis (SSc) and control subjects, using computational analysis software (TEPITOPE) and T cell proliferation assays.

Methods: Six oligopeptides, predicted by TEPITOPE software as potential topoisomerase protein epitopes, were used to perform T cell proliferation assays in 21 patients with SSc and 15 healthy controls.

Results: A positive response to at least one of the peptides was seen in 10/21 patients and $7 / 15$ healthy controls. Among responders, the proliferative response was limited to a single peptide in $6 / 7$ healthy controls, whereas $5 / 10$ patients responded to more than one peptide. In responding patients a significant correlation was found between disease duration and number of peptides inducing a response $(p=0.007)$. Conclusions: Several T cell epitopes of the topoisomerase I protein have been identified and evidence has been found to suggest epitope spreading in patients with SSc.
S ystemic sclerosis (SSc) is an autoimmune connective tissue disease characterised by fibrosis of the skin and internal organs. SSc-specific autoantibodies, present in $>70 \%$ of patients, ${ }^{1}$ are mostly mutually exclusive and are known to be associated with the different subsets of the disease. ${ }^{2}$ Anticentromere antibody is present in about $20-40 \%$ of patients and is linked to limited lung disease, whereas antitopoisomerase antibody (ATA), present in a similar proportion of patients, is strongly associated with the development of lung fibrosis. ${ }^{3}$ A high incidence of kidney and cardiac disease is associated with the presence of antibodies against RNA polymerase. ${ }^{3}$

Antitopoisomerase, the most studied of these antibodies, is directed against DNA topoisomerase I, a $105 \mathrm{kDa}$ nuclear enzyme involved in relaxation of supercoiled DNA. Although the pathogenetic role of these antibodies is not yet fully understood, serum autoantibodies have been reported to precede the development of overt clinical disease by several years in some patients with SSc. ${ }^{5}$ Several lines of evidence, though circumstantial at this time, suggest that the ATA plays a part in disease progression and outcome. Henry et al have shown that both ATA titres and the immunodominant domains recognised by ATA are highly variable over the course of the disease, suggesting continual antigen presentation and regulation of antibody response. ${ }^{7}$ The disappearance of ATA during the course of the disease is reported to be associated with milder pulmonary disease and improved survival. ${ }^{8}$ Similarly, lower levels of ATA at presentation are associated with a milder disease course. ${ }^{9}$ In addition, ATA levels have been shown to correlate positively with skin score and renal vascular resistance and negatively with pulmonary vital capacity. ${ }^{9}$

$\mathrm{T}$ and $\mathrm{B}$ cell collaboration is needed for the production of the autoantibody against topoisomerase I. ${ }^{10}$ ATA production is an antigen driven process (as opposed to an intrinsic T or B cell abnormality) requiring the presentation of the processed antigen by an antigen presenting cell with major histocompatibility complex (MHC) restriction to the T cell, resulting in proliferation and the induction of an antigen-specific response. ${ }^{11}$ In this context, the identification of immunodominant $\mathrm{T}$ cell epitopes of the protein is of particular relevance. We and others have shown that HLA class II alleles (DR11 and DR15) are associated with antibody status in patients with SSc. ${ }^{311}$ In addition, using large recombinant fragments of the protein, Kuwana et al have suggested that the immunodominant $\mathrm{T}$ cell epitopes of the protein are located between amino acids 276 and $386 .{ }^{12}$ In this study, using computational analysis software (TEPITOPE) and T cell proliferation assay to oligopeptides of topoisomerase I, we set out to identify the dominant epitopes which play a part in $\mathrm{T}$ cell activation.

\section{PATIENTS AND METHODS \\ Patients}

Twenty one patients with SSc and 15 healthy volunteers were included in this study. All patients with SSc visited the interstitial lung disease department of the Royal Brompton Hospital and fulfilled the American Rheumatism Association preliminary classification criteria for SSc. ${ }^{13}$ Clinical and laboratory findings were collected for the patients with SSc, including SSc disease classification (limited or diffuse), autoantibody status, disease duration at the time of the study (since the start of the first SSc symptoms other than Raynaud's phenomenon), and organ involvement (table 1). The presence of ATA was assessed by counterimmunoelectrophoresis. Consecutive patients attending the clinic during the study were enrolled in the study and controls were healthy volunteers from the institution. Informed consent was obtained from all subjects and the study was approved by the ethics committee at the Royal Brompton Hospital.

\section{Selection of peptides}

The TEPITOPE software was used to predict potential HLADR binding peptides of the human topoisomerase I protein, as described elsewhere. ${ }^{14}$ We used a version of TEPITOPE which incorporates 25 virtual matrices, covering most of the

\footnotetext{
Abbreviations: ATA, antitopoisomerase antibody; EAE, experimental autoimmune encephalomyelitis; IL, interleukin; MHC, major histocompatibility complex; PHA, phytohaemagglutinin; PLP, proteolipid protein; SI, stimulation index; SSc, systemic sclerosis; TNF $\alpha$, tumour
} necrosis factor $\alpha ; \Pi$, tetanus toxoid 
Table 1 Demographic features in patients with SSc with disease subtype (diffuse (D) or limited (L)), presence of specific antibodies, and organ involvement

\begin{tabular}{|c|c|c|c|c|c|c|c|c|}
\hline \multirow[b]{2}{*}{ Patients } & \multirow{2}{*}{$\begin{array}{l}\text { Age } \\
\text { (years) }\end{array}$} & \multirow[b]{2}{*}{ Sex } & \multirow{2}{*}{$\begin{array}{l}\text { Duration of } \\
\text { disease (years) }\end{array}$} & \multirow{2}{*}{$\begin{array}{l}\text { Disease } \\
\text { subtype }\end{array}$} & \multirow{2}{*}{$\begin{array}{l}\text { Peptides inducing } \\
\text { proliferation }\end{array}$} & \multirow{2}{*}{$\begin{array}{l}\text { Specific } \\
\text { antibodies }\end{array}$} & \multicolumn{2}{|c|}{ Organ involvement* } \\
\hline & & & & & & & Lung fibrosis & Other organs \\
\hline 1 & 64 & M & 4 & $D$ & None & ARA & Yes & Muscle \\
\hline 2 & 51 & $F$ & 4 & $D$ & None & ATA & Yes & \\
\hline 3 & 34 & $\mathrm{~F}$ & 9 & $\mathrm{~L}$ & None & ATA & Yes & \\
\hline 4 & 43 & $\mathrm{~F}$ & 18 & $\mathrm{~L}$ & $3,4,5,6$ & Th-RNP & No & Kidney \\
\hline 5 & 62 & M & 10 & $\mathrm{~L}$ & $3,4,5$ & ATA & Yes & Bowel \\
\hline 6 & 60 & $\mathrm{~F}$ & 8 & $\mathrm{~L}$ & None & ATA & Yes & \\
\hline 7 & 54 & $\mathrm{~F}$ & 9 & $\mathrm{~L}$ & 5 & ATA & Yes & \\
\hline 8 & 50 & $\mathrm{~F}$ & 5 & L & None & ATA & Yes & \\
\hline 9 & 33 & $\mathrm{~F}$ & 19 & L & None & ND & Yes & \\
\hline 10 & 66 & $\mathrm{~F}$ & 5 & $\mathrm{~L}$ & 5 & ND & Yes & \\
\hline 11 & 57 & $\mathrm{~F}$ & 16 & $D$ & 3,4 & APA & Yes & Muscle \\
\hline 12 & 57 & $F$ & 17 & $\mathrm{~L}$ & $3,5,6$ & $\mathrm{ACA}$ & No & \\
\hline 13 & 53 & $M$ & 15 & $D$ & 5 & ATA & Yes & Muscle \\
\hline 14 & 63 & $\mathrm{~F}$ & 22 & $\mathrm{~L}$ & None & ARA & Yes & \\
\hline 15 & 63 & $\mathrm{~F}$ & 3 & $D$ & 5 & ND & Yes & Bowel \\
\hline 16 & 56 & $\mathrm{~F}$ & 15 & $\mathrm{~L}$ & None & APA & Yes & Heart \\
\hline 17 & 55 & $\mathrm{~F}$ & 15 & L & $2,3,4,6$ & ND & Yes & \\
\hline 18 & 43 & $\mathrm{~F}$ & 4 & L & None & ND & Yes & Kidney \\
\hline 19 & 49 & $\mathrm{~F}$ & 3 & L & None & ND & Yes & \\
\hline 20 & 55 & $\mathrm{~F}$ & 2 & L & 5 & ATA & Yes & \\
\hline 21 & 55 & $\mathrm{~F}$ & 6 & L & None & ND & No & Bowel \\
\hline
\end{tabular}

human HLA class II peptide binding specificity. The prediction threshold was set at $3 \%$ and we identified 10 peptide sequences predicted to bind to the most common HLA-DR alleles (DRB1*0101, DRB1*0301, DRB1*0401, DRB1*0701, $\left.\mathrm{DRBI}^{*} 0801, \mathrm{DRBI}^{*} 1101, \mathrm{DRBI}^{*} 1501\right)$. From these 10 peptides, we selected five which encompass the area previously described $^{12}$ to include the immunodominant epitope of the protein and/or which were predicted to bind with DRB1*11 alleles, known to be associated with ATA production. Because two of these peptides (peptides 2 and 4) were adjacent to each other, we also obtained an overlapping peptide (peptide $3)$. The six peptides used in the proliferation assays were obtained from a commercial source (Chiron Technologies, Heswall, UK) and are shown in table 2. All peptides were $>95 \%$ pure except for peptide $4(>83 \%)$.

\section{T cell proliferation assay}

Peripheral blood $(20 \mathrm{ml})$ was drawn from the participating subjects into a heparin tube and peripheral blood mononuclear cells were separated on Ficoll-Paque (Amersham Pharmacia Biotech, Uppsala, Sweden). Isolated cells were washed and resuspended in RPMI 1640 medium (Life Technologies, Paisley, UK) supplemented with $5 \% \mathrm{vol} / \mathrm{vol}$ AB serum (Sigma, Poole, Dorset), 2 mM L-glutamine, $100 \mathrm{IU} /$ $\mathrm{ml}$ penicillin, and $100 \mu \mathrm{l} / \mathrm{ml}$ streptomycin (Life Technologies) and seeded out at $2 \times 10^{5}$ cells/well in a final volume of $200 \mu \mathrm{l}$ in round bottomed, 96 well microtitre plates (Nunclon, UK). All assays were performed at least in triplicate; the assays for

Table 2 Topoisomerase I peptides used in the study and their amino acid positions

\begin{tabular}{lll}
\hline $\begin{array}{l}\text { Peptide } \\
\text { number }\end{array}$ & Amino acid sequence & $\begin{array}{l}\text { Amino acid } \\
\text { position }\end{array}$ \\
\hline 1 & SQIEADFRLNDSHKHKD & $10-26$ \\
2 & HPKMGMLKRRIMPED & $367-381$ \\
3 & LKRRIMPEDIIINCS & $373-387$ \\
4 & PEDIIINCSKDAKVP & $379-393$ \\
5 & AKVFRTYNASITLQQQL & $586-602$ \\
6 & EKSMMNLQTKIDAKKE & $641-656$ \\
\hline
\end{tabular}

12 controls and 10 patients were done in sextuplicate. Tetanus toxoid (TT) and phytohaemagglutinin (PHA) were used at three different concentrations (TT, Evans Medical Ltd, UK at $8 \mathrm{IU} / \mathrm{ml}, 0.8 \mathrm{IU} / \mathrm{ml}$, and $0.08 \mathrm{IU} / \mathrm{ml}$; PHA Life Technologies at 1:10, 1:100, and 1:1000 dilution of the product) as positive controls. Cultures were incubated for 7 days in a humidified $5 \% \mathrm{CO}_{2}$ incubator at $37^{\circ} \mathrm{C}$, then pulsed for 16 hours with $5 \mathrm{mCi}$ of $\left[{ }^{3} \mathrm{H}\right]$ thymidine per well (Amersham Pharmacia Biotech, Little Chalfont, UK). The cells were then harvested, and incorporation of tritiated thymidine was measured by liquid scintillation counting. Results were expressed as a stimulation index (SI: counts per minute of antigen stimulated cultures divided by counts per minute of cultures in medium only). An SI $>2$ was regarded as a positive response. ${ }^{15}$

\section{Cytokine assays}

Six cytokines (interferon $\gamma$, tumour necrosis factor $\alpha$ (TNF $\alpha$ ), interleukin (IL)2, IL4, IL5, IL10) were simultaneously measured in the supernatant of cells stimulated with peptides 3 and 5 in all patients and controls by cytometric bead array, according to instructions provided by the manufacturer (BD Biosciences, San Jose, California). Peptide 5 and 3 were chosen, as the former induced a response in both patients and controls and the latter only in patients. Cytokine concentrations were determined from the standard curves provided by the manufacturer. If a sample had a cytokine concentration below the detection limit for the assay, a value of 0 was assigned.

\section{HLA typing}

Genomic DNA was extracted from peripheral blood lymphocytes by a modified version of the salting out method. ${ }^{16}$ HLA class II genotyping was carried out by polymerase chain reaction with sequence specific primers. HLA-DRB1, HLADRB3, HLA-DRB4, HLA-DRB5, and HLA-DQB1 were typed using the phototype method previously described. ${ }^{17}$ HLADPB 1 typing was carried out using a modified version of our 96-reaction method for comprehensive HLA-DPB and HLADPA typing, as previously described. ${ }^{2}$ The only alleles which cannot be distinguished by this method are HLA-DPBI*0801 and HLA-DPB1*1601, which differ at a single amino acid 
Table 3 HLA class II alleles and peptides inducing proliferation in patients with SSc

\begin{tabular}{|c|c|c|c|c|c|c|c|c|c|c|c|}
\hline \multirow{3}{*}{$\begin{array}{l}\text { Patients } \\
1\end{array}$} & \multirow{2}{*}{$\begin{array}{l}\text { Peptides } \\
\text { inducing } \\
\text { proliferation }\end{array}$} & \multirow{2}{*}{\multicolumn{2}{|c|}{ DRB 1 alleles }} & \multirow{2}{*}{\multicolumn{2}{|c|}{ DR alleles }} & \multirow{2}{*}{\multicolumn{2}{|c|}{ DQ alleles }} & \multirow{2}{*}{\multicolumn{2}{|c|}{ DP alleles }} & \multicolumn{2}{|c|}{ Organ involvement } \\
\hline & & & & & & & & & & \multirow{2}{*}{$\begin{array}{l}\text { Lung } \\
\text { Yes }\end{array}$} & \multirow{2}{*}{$\begin{array}{l}\text { Other } \\
\text { Muscle }\end{array}$} \\
\hline & None & 4 & 11 & 53 & 52 & $0301-4$ & $0301-4$ & 301 & 301 & & \\
\hline 2 & None & 1 & 11 & 1 & 52 & 5 & $0301-4$ & 201 & 402 & Yes & \\
\hline 3 & None & 15 & 1001 & 51 & 1 & 6 & 5 & 301 & 401 & Yes & \\
\hline 4 & $3,4,5,6$ & 11 & 4 & 52 & 53 & $0301-4$ & $0301-4$ & 401 & 401 & No & Kidney \\
\hline 5 & $3,4,5$ & 15 & 9 & 51 & 53 & 6 & 3032 & 401 & 1301 & Yes & Bowel \\
\hline 6 & None & 15 & 7 & 51 & 53 & 6 & 3032 & 401 & 1301 & Yes & \\
\hline 7 & 5 & 11 & 7 & 52 & 53 & $0301-4$ & $0301-4$ & 301 & 401 & Yes & \\
\hline 8 & None & 15 & 15 & 51 & 51 & 6 & 6 & 201 & 1801 & Yes & \\
\hline 9 & None & 3 & 14 & & & 2 & 5 & 401 & 401 & Yes & \\
\hline 10 & 5 & 1 & 8 & 1 & 8 & 5 & 4 & 401 & 401 & Yes & \\
\hline 11 & 3,4 & 3 & 13 & 52 & 52 & 201 & 6 & 401 & 1301 & Yes & Muscle \\
\hline 12 & $3,5,6$ & 4 & 1 & 53 & 1 & $0301-4$ & 5 & 301 & 301 & No & \\
\hline 13 & 5 & 15 & 4 & 51 & 53 & 6 & $0301-4$ & 401 & 401 & Yes & Muscle \\
\hline 14 & None & 15 & 3 & 51 & 52 & 6 & 2 & 101 & 1001 & Yes & \\
\hline 15 & 5 & 1 & 7 & 1 & 53 & 5 & 2 & 101 & 402 & Yes & Bowel \\
\hline 16 & None & 13 & 3 & 52 & 52 & 6 & 2 & 402 & 501 & Yes & Heart \\
\hline 17 & $2,3,4,6$ & 15 & 4 & 51 & 53 & 6 & $0301-4$ & 401 & $801 / 1601$ & Yes & \\
\hline 18 & None & 15 & 3 & 51 & 52 & 6 & 2 & 201 & 401 & Yes & Kidney \\
\hline 19 & None & 3 & 13 & 52 & 52 & 2 & 6 & 301 & 401 & Yes & \\
\hline 20 & 5 & 15 & 7 & 51 & 53 & 6 & 2 & 401 & 1101 & Yes & \\
\hline 21 & None & 8 & 1001 & 8 & 1 & 4 & 5 & 301 & 901 & No & Bowel \\
\hline
\end{tabular}

residue. For the purposes of this paper, these have been considered together.

\section{Statistics}

Frequency comparisons between two groups were made using $\chi^{2}$ statistics, or, where appropriate, Fisher's exact test. Spearman's rank correlation test was used to evaluate the correlation between the duration of disease and the number of peptides inducing a proliferative response, as well as the correlation between supernatant cytokines and cell proliferation measures. A Wilcoxon rank sum test was used for the comparison of supernatant cytokine levels between patients and controls as well as between responders and nonresponders.

\section{RESULTS}

HLA class II alleles in patients with SSc and healthy donors

Tables 3 and 4 list the HLA-DR, DP, and DQ alleles of the patients with SSc and healthy donors, respectively. No differences in the distribution of the HLA alleles between patients with SSc and controls were found except for a slight overrepresentation of $\mathrm{DPBI}{ }^{*} 0401$ in patients compared with controls $(13 / 21 \vee 4 / 15, \mathrm{p}=0.035)$. In particular, 13/21 patients had either HLA-DRll or 15 in comparison with $9 / 15$ controls $(p=N S)$. However, all eight patients with ATA had either DRll or 15 in comparison with 5/13 ATA negative patients with SSc (Fisher's exact test, $\mathrm{p}=0.006$ ).

\section{T cell proliferation}

Table 5 shows the proliferative responses of peripheral blood mononuclear cells cultured for 7 days with the peptides. All patients and controls responded to TT and PHA. A positive proliferative response to at least one of the peptides was seen in 10/21 patients and 7/15 healthy controls. In six of the healthy controls, the response was limited to a single peptide. Only one healthy control had a proliferative response to two of the six tested peptides. Half of the responding patients had proliferation to more than one peptide. There was no statistically significant difference between the patients and controls (Fisher's exact test) for responders versus nonresponders or for the number of subjects responding to a single peptide.

The peptides differed in their ability to induce a proliferative response. Figure 1 shows the change in the number of counts per minute in responders and non-responders. As

Table 4 HLA class II alleles and peptides inducing proliferation in healthy controls

\begin{tabular}{|c|c|c|c|c|c|c|c|c|c|c|c|}
\hline \multirow{2}{*}{$\begin{array}{l}\text { Controls } \\
1\end{array}$} & \multirow{2}{*}{$\begin{array}{l}\begin{array}{l}\text { Age } \\
\text { (years) }\end{array} \\
27\end{array}$} & \multirow{2}{*}{$\frac{\text { Sex }}{M}$} & \multirow{2}{*}{$\begin{array}{l}\text { Peptides } \\
\text { inducing } \\
\text { proliferation }\end{array}$} & \multicolumn{2}{|c|}{ DRB Ialleles } & \multicolumn{2}{|c|}{ DR alleles } & \multicolumn{2}{|c|}{ DQ alleles } & \multicolumn{2}{|c|}{ DP alleles } \\
\hline & & & & 15 & 13 & 51 & 52 & 6 & $0301-4$ & 901 & 1701 \\
\hline 2 & 32 & M & None & 7 & 11 & 53 & 52 & 2 & $0301-4$ & 1401 & 1701 \\
\hline 3 & 25 & M & None & 15 & 7 & 51 & 53 & 6 & 2 & 1101 & 1101 \\
\hline 4 & 31 & $\mathrm{~F}$ & None & 11 & 3 & 52 & 52 & $0301-4$ & 2 & 401 & $801 / 1601$ \\
\hline 5 & 26 & $\mathrm{~F}$ & None & 3 & 11 & 52 & 52 & 2 & $0301-4$ & 201 & 201 \\
\hline 6 & 33 & $\mathrm{~F}$ & None & 3 & 11 & 52 & 52 & 2 & $0301-4$ & 201 & 1001 \\
\hline 7 & 35 & $\mathrm{~F}$ & 5 & 4 & 13 & 53 & 52 & $0301-4$ & 6 & 301 & 301 \\
\hline 8 & 36 & $\mathrm{~F}$ & 5 & 8 & 9 & 8 & 53 & 0302 & 3032 & 501 & $801 / 1601$ \\
\hline 9 & 35 & M & 5 & 3 & 15 & 52 & 51 & 2 & 6 & 402 & 1401 \\
\hline 10 & 35 & $M$ & 4 & 13 & 11 & 52 & 52 & 6 & $0301-4$ & 201 & 1001 \\
\hline 11 & 32 & $\mathrm{~F}$ & 5 & 9 & 3 & 53 & 52 & 3032 & 2 & 501 & 501 \\
\hline 12 & 32 & $\mathrm{~F}$ & 2,5 & 11 & 11 & 52 & 52 & $0301-4$ & $0301-4$ & 401 & 402 \\
\hline 13 & 37 & $M$ & None & 3 & 16 & 52 & 51 & 2 & 5 & 201 & 402 \\
\hline 14 & 24 & $\mathrm{~F}$ & 5 & 4 & 13 & 53 & 52 & $0301-4$ & 6 & 201 & 401 \\
\hline 15 & 39 & $\mathrm{~F}$ & None & 14 & 1 & 52 & 1 & 5 & 5 & 101 & 401 \\
\hline
\end{tabular}


Table 5 Comparison of mean (SD) stimulation index and percentage of responders for each of the peptides in patients and controls

\begin{tabular}{|c|c|c|c|c|}
\hline \multirow[b]{2}{*}{ Peptide } & \multicolumn{2}{|l|}{ Patients } & \multicolumn{2}{|l|}{ Controls } \\
\hline & SI & Responders (\%) & SI & Responders (\%) \\
\hline 1 & $1.17(0.41)$ & 0 & $1.10(0.38)$ & 0 \\
\hline 2 & $1.20(0.47)$ & 4.8 & $1.06(0.47)$ & 6.7 \\
\hline 3 & $1.45(0.68)^{*}$ & $23.8 \ddagger$ & $0.98(0.36)$ & 0 \\
\hline 4 & $1.44(0.70)$ & 19 & $1.19(0.39)$ & 6.7 \\
\hline 5 & $1.81(0.66)$ & 38.1 & $2.31(1.79)$ & 40 \\
\hline 6 & $1.45(0.67) \dagger$ & 14.3 & $1.06(0.45)$ & 0 \\
\hline
\end{tabular}

seen in the figure none of the patients or controls responded to peptide 1. In contrast, among responders, peptide 5 was highly antigenic, inducing a proliferative response in 6/7 controls and in 8/10 patients with SSc. Peptides 3 and 6 were highly specific for patients, with none of the controls having a proliferative response; the difference was significant for peptide $3(\mathrm{p}=0.05)$. Also, in the whole group, there was a significant difference in the mean SI between patients and controls for peptide $3(\mathrm{p}=0.02)$ and a trend for peptide 6 $(\mathrm{p}=0.055)$ as shown in table 5 .

To assess cytokine production in response to topoisomerase peptides, we evaluated the levels of six cytokines (interferon $\gamma, \mathrm{TNF} \alpha$, IL2, IL4, IL5, and IL10) in the supernatant of cells stimulated with peptides 3 and 5. Moderately higher levels of IL4 were seen in responders to peptide 3 than in nonresponders, with a $\mathrm{p}$ value bordering on significance (median values $5.6 v 2.6, \mathrm{p}=0.067)$. However, most samples were characterised by low levels of this cytokine. No significant differences were seen for the other cytokines between responders and non-responders. Interestingly, IL5 levels in response to both peptides 3 and 5 were lower in patients with SSc than in controls $(\mathrm{p}<0.005$ for both comparisons),
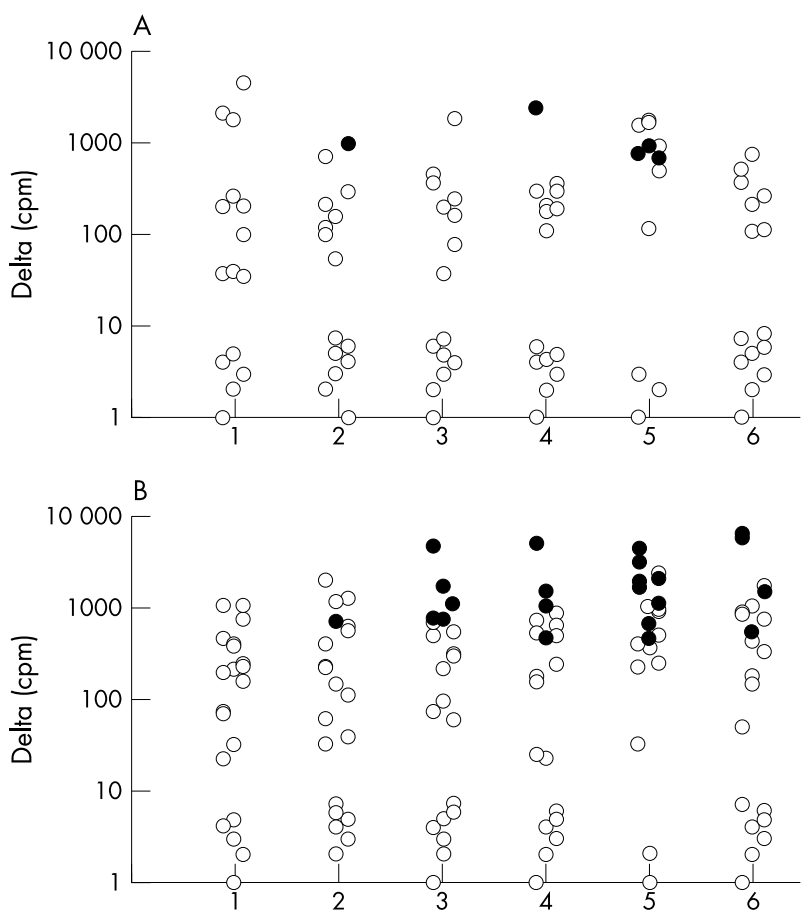

Figure 1 Dot histogram showing the average change in the number of counts per minute $(\Delta \mathrm{cpm})$ for the proliferation assays to each of the peptides in controls (A) and patients with SSc (B). Filled circles show reactions with an $\mathrm{SI}>2$. whereas other cytokines were similar between the two groups. As expected, a significant correlation was seen between IL2 supernatant levels and cell proliferation ( $\mathrm{cpm})$, both in the samples treated with peptide 3 and peptide 5 (Spearman's $r_{\mathrm{s}}=0.67$ and 0.69 , respectively, $\mathrm{p}<0.00001$ ).

We also analysed the HLA-DR, DP, and DQ alleles of the responders and non-responders in both controls and patients. We found no significant correlation between any of the HLA alleles and response to the peptides. Subjects with HLADRBI*03 were likely to be non-responders (9/12 v 10/24 non-responders in subjects with and without DRB1*03, respectively), though this did not reach significance (Fisher's exact test $p=0.06$ ). We did not observe the previously reported association between $\mathrm{T}$ cell proliferation to topoisomerase I and homozygosity to the amino acid tyrosine at position 30 of the HLA-DQBl allele. ${ }^{18}$

The predictive ability of the TEPITOPE program was also studied. Ninety per cent of the proliferation responses in the experiment were predicted by TEPITOPE.

\section{Clinical features and response to peptides}

The relationship between response to peptides and clinical findings was analysed. Eight of the 21 patients were positive for ATA antibodies. The presence of ATA, as well as the type of disease, limited or diffuse, was not related to response to peptides in the patient group.

In patients who responded, the relationship between the duration of the disease and the number of peptides inducing proliferation was investigated. We found a significant correlation $\left(r_{\mathrm{s}}=0.74, \mathrm{p}=0.007\right)$ between disease duration and the number of peptides (fig 2 ). This was not a function of age, as no correlation was seen between the number of peptides and the age of the patients $\left(r_{\mathrm{s}}=-0.22, \mathrm{p}=0.27\right)$. Similarly, there was no correlation between sex and proliferative response either in patients or controls or both groups combined (Fisher's exact test, patients $\mathrm{p}=0.59$,

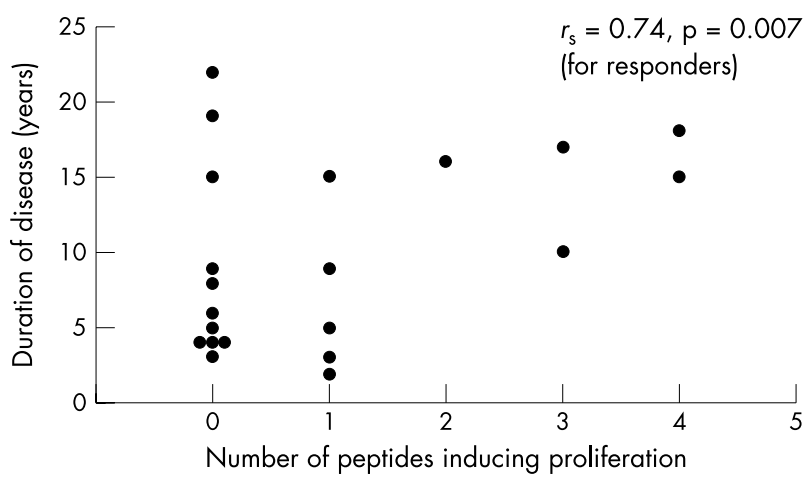

Figure 2 Significant correlation between disease duration and number of peptides inducing proliferation in patients with SSc. 
controls $p=0.61)$. Interestingly, there was no difference in the duration of disease between responders and nonresponders.

\section{DISCUSSION}

The identification of the T cell epitopes of the 765 amino acid long topoisomerase I protein by conventional methods is a laborious process, which involves obtaining short overlapping oligopeptides of the complete protein. We therefore used a computer designed algorithm, the TEPITOPE program, to simplify the identification of specific HLA restricted $\mathrm{T}$ cell epitopes. The program predicts the potential of a peptide to bind to a particular MHC molecule using MHC-peptide binding and structural data. ${ }^{14}$ The number of potential peptides can be significantly reduced by this method. The program depends on the affinity of the peptides but cannot predict processing, proteolysis, or availability of the peptide on the cell surface. Thus, several of the peptides predicted to bind to a particular HLA allele did not induce a proliferation response, whereas nearly $90 \%$ of the proliferation responses observed were predicted by the program. Kwok et al compared the predictive ability of the TEPITOPE program with tetramer guided epitope mapping and found similar results. ${ }^{19}$ In this study we identified a number of $\mathrm{T}$ cell epitopes of the topoisomerase protein; however, these may represent only part of the $\mathrm{T}$ cell repertoire that exists in vivo.

The differences in epitope response found in patients with SSc compared with controls might have been affected by differences in age and sex distribution between the two groups. However, we did not observe an increasing number of responses to peptides with older age, as would be expected if age were a significant factor. Indeed, an association in the opposite direction (albeit not significant) was found. Similarly, there was no difference (significant or marginal) in the sex of responders in controls or patients or both groups combined, indicating that demographic factors did not confound the observed associations.

Among patients with SSc, there was no difference in the duration of disease between responders and non-responders. This finding may reflect a fundamental distinction between the initiation and progression of a pathogenetic process. T cell autoreactivity to topoisomerase I occurs in a subgroup of patients with SSc, perhaps influenced by genetic factors. Our observation of epitope spreading applies to this subgroup. The fact that non-responsive patients do not have a shorter duration of disease is in keeping with a dichotomy between initiation and progression. Thus it can be argued that for $\mathrm{T}$ cell responses to topoisomerase, two immunological subsets of patients with SSc exist: the first develops a proliferative response to topoisomerase, and goes on to manifest epitope spreading, the second never develops a response, irrespective of the duration of the disease.

The findings of proliferative responses to peptides in healthy subjects, as well as the absence of a relationship between ATA and proliferative responses in patients with SSc, are not unexpected. These observations are in keeping with the previously reported finding of proliferative responses to topoisomerase I fragments in patients with SSc with and without ATA as well as in healthy controls. ${ }^{20}$ Indeed, in monozygotic twins discordant for SSc and ATA, both twins have been shown to have a proliferative response to topoisomerase I with only the diseased twin producing ATA in an in vitro B cell culture. ${ }^{21}$ Interestingly, some patients had ATA but not a T cell response to the selected peptides. This might be secondary to the disappearance of $\mathrm{T}$ cell responses over time or after treatment, as shown in patients who have received a kidney transplant, ${ }^{22}$ while memory $\mathrm{B}$ cells persist. Production of antibodies by B cells can persist and outlast specific memory $\mathrm{T}$ cells; mechanisms involved are likely to include polyclonal stimuli, such as microbial products or noncognate (aspecific) T cell help. ${ }^{23}$ Alternatively, patients with ATA but no proliferative response to the selected peptides may be responsive to other epitopes present in the topoisomerase protein, including those identified by the TEPITOPE software but not selected for this study.

We found no clear association between the proliferative responses to the peptides and the supernatant cytokine profiles. Interestingly, we observed lower levels of the Th2type cytokine IL5 in patients than in controls, independent of the response to topoisomerase peptides. Although several studies suggest that scleroderma is predominantly a Th2 response disease, ${ }^{24}{ }^{25}$ others have reported a significant shift towards a Thl response in SSc peripheral T cells. ${ }^{26}{ }^{27}$ These discrepancies may be secondary to a series of factors, including differences in disease sites, $\mathrm{T}$ lymphocyte subsets, methods, and timing of cytokine measurement, indicating the need for further investigation in this area.

We found that peptide 3 , the oligopeptide inducing a proliferative response in $50 \%$ of SSc responders but in none of the controls, lies in the area suggested by Kuwana et al (amino acids 276-386) to contain an immunodominant epitope. ${ }^{12}$ However, we did not find any significant association between peptide induced proliferation and HLA alleles. Kuwana and colleagues have previously shown that proliferation to topoisomerase protein is restricted by the presence of particular DR alleles; both in patients and in healthy controls, the presence of HLA-DRBI*11, DRB1*15, or $\mathrm{DRBI}^{*} 07$ was related to $\mathrm{T}$ cell proliferation to the topoisomerase protein..$^{20}$ The presence of a strong relationship with HLA alleles described in Kuwana's study and not in ours is possibly related to the size of the antigen used. Compared with its constituent oligopeptide components, large protein fragments have been shown to elicit a substantially different proliferative response. ${ }^{28}$ This may be a key factor in explaining the discrepancy with our findings, as Kuwana et al used six large soluble recombinant topoisomerase I fusion proteins encompassing the entire topoisomerase I sequence of 765 amino acids, compared with the short oligopeptides used in this study.

Kuwana et al, using large topoisomerase I fragments, showed that topoisomerase I-specific T cell clones both from patients with SSc and from healthy controls have relatively homogeneous epitope reactivity. ${ }^{12}$ By contrast, using oligopeptides, we have shown significant differences in epitope reactivity between patients and controls. The reactivity to a single peptide (peptide 5 ) by most of the subjects displaying a proliferative response, whether patients or controls, suggests that the presence of autoreactive $\mathrm{T}$ cells is a feature occurring in the general population, possibly owing to failure in the thymus of $\mathrm{T}$ cell down regulation to particular epitopes of proteins, as described for other self antigens such as proteolipid protein in SJL mice (proteolipid protein (PLP) 139-151) and humans $\left(\mathrm{PLP}_{40-60}\right) .^{29}{ }^{30}$

In this study we have shown that patients with SSc have proliferative responses to a larger number of peptides compared with controls. This observation, together with the finding of a significant correlation between the number of peptides inducing a response and the duration of the disease, suggests epitope spreading. This phenomenon consists of the diversification of the immune response from the initial dominant epitope to other epitopes found on the same or other proteins. Epitope spreading has a crucial role in several autoimmune disease models, including experimental autoimmune encephalomyelitis (EAE) and Theiler's murine encephalitogenic, virus induced demyelinating disease. The induction of EAE by administration of any myelin protein epitope other than $\mathrm{PLP}_{139-151}$ results at first in the appearance of $\mathrm{T}$ cells specific for $\mathrm{PLP}_{139-151}$, followed by a 
hierarchical order of epitope spreading. ${ }^{31}{ }^{32}$ In these models of multiple sclerosis, the blocking of epitope spreading, either by inducing tolerance to spread myelin epitopes or by blocking costimulation of $\mathrm{T}$ cells, inhibits continuing clinical disease. ${ }^{33}$ In relapsing EAE, CTLA-4, a negative regulator of $\mathrm{T}$ cell function, down regulates epitope spreading; moreover, CTLA4 blockade during acute disease prevents remission. ${ }^{3435}$ Similarly, in non-obese diabetic mice, a well known autoimmune diabetic mice model, induction of early tolerance to glutamic acid decarboxylase blocks epitope spreading and disease progression. ${ }^{36}$ The finding of epitope spreading and the evidence for continual presentation of antigen during the course of the disease in $\mathrm{SSc}^{7}$ indicates that identification of the specific peptides inducing the immune response may be an important step in the immunological management of the disease. The unravelling of the immunological basis of SSc will hopefully lead to the development of new and effective immune modifying treatments to replace current conventional treatments, which have limited success.

\section{ACKNOWLEDGEMENTS}

This work was supported by the Raynaud's and Scleroderma Association, UK.

\section{Authors' affiliations}

S Veeraraghavan, E A Renzoni, H Jeal, M Jones, A U Wells, K I Welsh, R M du Bois, Interstitial Lung Disease Unit, Department of Occupational Medicine, National Heart and Lung Institute, Royal Brompton Hospital and Imperial College of Science Technology and Medicine, London, UK J Hammer, Genetics and Genomics Section, Roche Pharmaceuticals, Nutley, NJ, USA

C M Black, Department of Academic Rheumatology, Royal Free Hospital, London, UK

The work was done at the Royal Brompton Hospital, London, UK

\section{REFERENCES}

1 Harvey GR, Butts S, Rands AL, Patel Y, McHugh NJ. Clinical and serological associations with anti-RNA polymerase antibodies in systemic sclerosis. Clin Exp Immunol 1999;117:395-402.

2 Fanning GC, Welsh KI, Bunn C, Du Bois R, Black CM. HLA associations in three mutually exclusive autoantibody subgroups in UK systemic sclerosis patients. BrJ Rheumatol 1998;37:201-7.

3 Gilchrist FC, Bunn C, Foley PJ, Lympany PA, Black CM, Welsh KI, et al. Class II HLA associations with autoantibodies in scleroderma: a highly significant role for HLA-DP. Genes Immun 2001;2:76-81.

4 Kuwana M, Kaburaki J, Okano Y, Tojo T, Homma M. Clinical and prognostic associations based on serum antinuclear antibodies in Japanese patients with systemic sclerosis. Arthritis Rheum 1994;37:75-83.

5 Weiner ES, Hildebrandt S, Senecal JL, Daniels L, Noell S, Joyal F, et al. Prognostic significance of anticentromere antibodies and anti-topoisomerase I antibodies in Raynaud's disease. A prospective study. Arthritis Rheum 1991;34:68-77.

6 Kallenberg CG, Wouda AA, Hoet MH, van Venrooij WJ. Development of connective tissue disease in patients presenting with Raynaud's phenomenon: a six year follow up with emphasis on the predictive value of antinuclear antibodies as detected by immunoblotting. Ann Rheum Dis 1988;47:634-41.

7 Henry PA, Atamas SP, Yurovsky VV, Luzina I, Wigley FM, White B. Diversity and plasticity of the anti-DNA topoisomerase I autoantibody response in scleroderma. Arthritis Rheum 2000;43:2733-42.

8 Kuwana M, Kaburaki J, Mimori T, Kawakami Y, Tojo T. Longitudinal analysis of autoantibody response to topoisomerase I in systemic sclerosis. Arthritis Rheum 2000;43:1074-84.

9 Sato S, Hamaguchi Y, Hasegawa M, Takehara K. Clinical significance of antitopoisomerase I antibody levels determined by ELISA in systemic sclerosis. Rheumatology (Oxford) 2001;40:1135-40.

10 Kuwana M, Medsger TA Jr, Wright TM. T and B cell collaboration is essential for the autoantibody response to DNA topoisomerase I in systemic sclerosis. $\mathrm{J}$ Immunol 1995;155:2703-14.

11 Kuwana M, Kaburaki J, Okano Y, Inoko H, Tsuji K. The HLA-DR and DQ genes control the autoimmune response to DNA topoisomerase I in systemic sclerosis (scleroderma). J Clin Invest 1993;92:1296-301.
12 Kuwana M, Medsger TA Jr, Wright TM. Highly restricted TCR-alpha beta usage by autoreactive human T cell clones specific for DNA topoisomerase I: recognition of an immunodominant epitope. J Immunol 1997; 158:485-91.

13 Preliminary criteria for the classification of systemic sclerosis (scleroderma). Subcommittee for scleroderma criteria of the American Rheumatism Association Diagnostic and Therapeutic Criteria Committee. Arthritis Rheum 1980;23:581-90.

14 Sturniolo T, Bono E, Ding J, Raddrizzani L, Tuereci O, Sahin U, et al. Generation of tissue-specific and promiscuous HLA ligand databases using DNA microarrays and virtual HLA class II matrices. Nat Biotechnol 1999; 17:555-61.

15 Abulafia-Lapid R, Elias D, Raz I, Keren-Zur Y, Atlan H, Cohen IR. T cell proliferative responses of type 1 diabetes patients and healthy individuals to human hsp60 and its peptides. J Autoimmun 1999;12:121-9.

16 Miller SA, Dykes DD, Polesky HF. A simple salting out procedure for extracting DNA from human nucleated cells. Nucleic Acids Res 1988;16:1215.

17 Bunce M, Fanning GC, Welsh KI. Comprehensive, serologically equivalent DNA typing for HLA-B by PCR using sequence-specific primers (PCR-SSP). Tissue Antigens 1995:45:81-90.

18 Rands AL, Whyte J, Cox B, Hall ND, McHugh NJ. MHC class II associations with autoantibody and $T$ cell immune responses to the scleroderma autoantigen topoisomerase I. J Autoimmun 2000;15:451-8.

19 Kwok WW, Gebe JA, Liu A, Agar S, Ptacek N, Hammer J, et al. Rapid epitope identification from complex class-II-restricted T-cell antigens. Trends Immunol $2001 ; 22: 583-8$.

20 Kuwana M, Medsger TA Jr, Wright TM. T cell proliferative response induced by DNA topoisomerase I in patients with systemic sclerosis and healthy donors. J Clin Invest 1995;96:586-96.

21 Kuwana M, Feghali CA, Medsger TA Jr, Wright TM. Autoreactive T cells to topoisomerase I in monozygotic twins discordant for systemic sclerosis. Arthritis Rheum 2001:44:1654-9.

22 Welsh KI, Bunce M. HLA typing, matching and crossmatching in renal transplantation. In: Morris PJ, ed. Kidney transplantation, 5th ed. Philadelphia: Saunders, 2001:135-58.

23 Bernasconi NL, Traggiai E, Lanzavecchia A. Maintenance of serological memory by polyclonal activation of human memory B cells. Science 2002;298:2199-202.

24 Needleman BW, Wigley FM, Stair RW. Interleukin-1, interleukin-2, interleukin-4, interleukin-6, tumor necrosis factor alpha, and interferongamma levels in sera from patients with scleroderma. Arthritis Rheum 1992;35:67-72.

25 Mavalia C, Scaletti C, Romagnani P, Carossino AM, Pignone A, Emmi L, et al. Type 2 helper T-cell predominance and high CD30 expression in systemic sclerosis. Am J Pathol 1997;151:1751-8.

26 Valentini G, Baroni A, Esposito K, Naclerio C, Buommino E, Farzati A, et al. Peripheral blood T lymphocytes from systemic sclerosis patients show both Th1 and Th2 activation. J Clin Immunol 2001;21:210-17.

27 Fujii H, Hasegawa M, Takehara K, Mukaida N, Sato S. Abnormal expression of intracellular cytokines and chemokine receptors in peripheral blood T lymphocytes from patients with systemic sclerosis. Clin Exp Immunol 2002;130:548-56.

28 Oriss TB, Hu PQ, Wright TM. Distinct autoreactive T cell responses to native and fragmented DNA topoisomerase I: influence of APC type and IL-2. $\mathrm{J}$ Immunol 2001; 166:5456-63

29 Trotter JL, Pelfrey CM, Trotter AL, Selvidge JA, Gushleff KC, Mohanakumar T, et al. T cell recognition of myelin proteolipid protein and myelin proteolipid protein peptides in the peripheral blood of multiple sclerosis and control subjects. J Neuroimmunol 1998;84:172-8.

30 Anderson AC, Nicholson LB, Legge KL, Turchin V, Zaghouani H, Kuchroo VK. High frequency of autoreactive myelin proteolipid protein-specific $T$ cells in the periphery of naive mice: mechanisms of selection of the self-reactive repertoire. J Exp Med 2000;191:761-70.

31 Vanderlugt CL, Neville KL, Nikcevich KM, Eagar TN, Bluestone JA, Miller SD. Pathologic role and temporal appearance of newly emerging autoepitopes in relapsing experimental autoimmune encephalomyelitis. J Immunol 2000;164:670-8

32 McRae BL, Vanderlugt CL, Dal Canto MC, Miller SD. Functional evidence for epitope spreading in the relapsing pathology of experimental autoimmune encephalomyelitis. J Exp Med 1995; 182:75-85.

33 Vanderlugt CL, Miller SD. Epitope spreading in immune-mediated diseases: implications for immunotherapy. Nature Rev Immunol 2002;2:85-95.

34 Karandikar NJ, Eagar TN, Vanderlugt CL, Bluestone JA, Miller SD. CTLA-4 downregulates epitope spreading and mediates remission in relapsing experimental autoimmune encephalomyelitis. J Neuroimmunol 2000;109:173-80.

35 Karandikar NJ, Vanderlugt CL, Walunas TL, Miller SD, Bluestone JA. CTLA-4: a negative regulator of autoimmune disease. J Exp Med 1996;184:783-8.

36 Kaufman DL, Clare-Salzler M, Tian J, Forsthuber T, Ting GS, Robinson P, et al. Spontaneous loss of T-cell tolerance to glutamic acid decarboxylase in murine insulin-dependent diabetes. Nature 1993;366:69-72. 